\title{
EL DISCURSO DE AUTOAFIRMACIÓN DE LA MUJER A TRAVÉS DE LA NOVELA
}

\author{
María del Mar Rivas Carmona \\ Universidad de Sevilla
}

\begin{abstract}
This study presents a historical perspective of women's discursive practice while seeking to assert self-identity through novel writing. It includes several outstanding female authors spanning a long period from the beginnings of the novel proper to the last years of the $20^{\text {th }}$ century. It focuses on their use of key linguistic items bearing some discursive value that determines their ideological stand with respect to their historical moment. I conclude by assessing the female search for identity as going back to centuries ago when women determined their own role as novelists.
\end{abstract}

\section{INTRODUCCIÓN}

Desde los comienzos de la novela escrita por mujeres hemos encontrado heroínas valerosas que intuían un 'algo más' y que poseían una necesidad de más conocimientos y experiencias para poder apreciar la realidad de la vida. A través de los siglos se ven repetidos esquemas tales como: el abandono del campo a la ciudad, las ansias por viajar y conocer nuevas gentes, deseos de leer y adquirir conocimientos, la lucha por descubrir las propias posibilidades y desarrollarlas, la búsqueda de trabajos, nuevos amores o aventuras, o la necesidad de lograr auto-confianza y encontrarse a sí mismas. Tales esquemas se convierten en uno de los más significativos hilos conductores de la tradición en novela escrita por mujer.

En la mayor parte de las novelas escritas en el siglo XX nos encontramos ya con personajes femeninos que gozan de una serie de posibilidades y oportunidades mayor de la que habían tenido hasta entonces. Durante los años sesenta esta nueva perspectiva supuso uno de los cambios sociales más radicales:

Not only had the 'New Morality' begun to challenge received perceptions of gender, sexuality, and marriage, but new patterns in women's employment, and particularly professional employment, had steadily emerged since the end of the Second World War (Sanders 1994: 614).

A partir de los años setenta esta nueva y amplia perspectiva se reflejará significativamente en las novelas y sus protagonistas femeninas. Serán unos cambios históricos que requieren estudio aparte, pues la trayectoria reivindicativa seguida desde los inicios de la novela femenina, hacia finales del XVII, empieza a dar frutos y a realizarse paulatinamente en una amplia gama de posibilidades para la mujer. Así pues, el presente estudio pretende ofrecer una breve perspectiva histórica y una línea de continuidad en el discurso femenino de autoafirmación y búsqueda de la propia identidad desde los inicios de la novela inglesa hasta los años 70 del pasado siglo. 


\section{Primieras EXPRESIONES DE AUTO-REALIZACIÓN}

En plenos albores de la novela, autoras como Margaret Cavendish o Dorothy Osborne comienzan a escribir entre lo público y lo privado en el estilo llano que triunfaba. Margaret Cavendish, la duquesa de Newcastle, vio gran parte de su obra publicada por gusto propio, aunque su valentía en la actividad literaria le costó el apodo de "Mad Madge" de parte de sus contemporáneos. ${ }^{1}$ En su obra The Contract $(1656)^{2}$ presenta a una protagonista, Lady Deletia, que abandonaba el campo hacia la capital en "búsqueda de un futuro y una educación" en compañía de su tío y tutor (TC: 7). Deletia sabe que, gracias a su extraordinaria belleza, le sería fácil encontrar un buen partido, aspiración de la generalidad de las mujeres de entonces pero, para ella, la realización de la personalidad de una mujer supone algo más que atraer a los hombres:

[...]if I be, said she, thought handsome, what then? Why then, answered she herself, I shall be cried up to be a beauty; and what then? Then I shall have eyes stare upon me; and what am II the better, unless their eyes could infuse in my brain, wit and understanding? Their eyes cannot enrich me with knowledge, nor give me the light of truth; for I cannot see with their eyes, nor hear with their ears, no more than their meat can nourish me which they do eat, or rest when they do sleep (TC: 11$)$.

La repetición del pronombre de primera persona supone en sí toda una auto-afirmación frente a la tercera persona de "ellos" (los hombres). En este acusado contraste, Deletia evita denominarlos "hombres", directamente, refiriéndose a partes de su cuerpo: "their eyes", "their ears", etc.

En The Blazing World (1666), también de Margaret Cavendish, la "búsqueda de conocimiento" por parte de la protagonista se convierte en uno de los motores fundamentales de la obra. La emperatriz de ese mundo fantástico en el que se sitúa la acción desea, ante todo, saber: "before all things (she) desired to be informed (...)" (BW: 134). Para ella, las mujeres no deben estar apartadas del conocimiento y participa activamente en discusiones sobre astrología, geología, medicina, física, química o filosofía:

(1) [...] she spent most of her time in the study of natural causes and effects, which was her chief delight and pastime, and [...] she loved to discourse sometimes with the most learned persons of that world $[\ldots](B W: 222)$.

También la heroína "quijotesca" de Charlotte Lennox (The Female Quixote, 1752) Arabella, debido a una vida confinada en un castillo inglés, ha dado rienda suelta a su imaginación a través de la lectura de novelas populares francesas. Aventurera y romántica al igual que su propia autora ${ }^{4}$, en contra de la costumbre, desacata el testamento paterno que la obliga a contraer matrimonio contra su voluntad y, como las heroínas de los romances

\footnotetext{
${ }^{1}$ También Aphra Behn, la primera escritora profesional de Inglaterra, era considerada "a shady lady" (una dama turbia). Irremisiblemente las escritoras que no se disculpaban por su actividad literaria en su obra eran consideradas como locas, monstruosos o poco femeninas (Vid. Gilbert y Gubar 1979: 63).

${ }^{2}$ M. Cavendish, The Blazing World and Other Writings, Harmondsworth, Penguin, [1656; 1666] 1992. De ahora en adelante, TC (The Contract) y BW (The Blazing World). Las negritas son de la autora del artículo.

${ }^{3}$ C. Lennox, The Female Quixote, Oxford, Oxford University Press. (World's Classics), [1752] 1989. De ahora en adelante, $F Q$.

${ }^{4}$ La vida de Charlotte Lennox fue también activa y aventurera. (Cfr. Doody 1989: XI).
} 
caballerescos, decide poseer siempre el "control de su propia vida"": sólo la locura podía justificar que una mujer se atreviese a esto. Además, establece numerosas relaciones sociales y efectúa muchos viajes: Bath ( $F Q: 262)$, Londres ( $F Q: 330)$, Richmond ( $F Q: 340)$.

En Evelina $(1778)^{6}$ Fanny Burney, primera novelista inglesa de prestigio, retrata la historia de una chica de provincias que "abandona el campo"7. Como el propio título indica, The History of a Young Lady's Entrance into the World, esto le supone conocer un nuevo mundo. En un principio tímida e insegura ("I am half ashamed of myself..." (EV: 23)), a través de experiencias a menudo dolorosas ("Oh, Sir! why have I ever quitted you! why been exposed to dangers to which I am so unequal?" (EV: 322)), como suele ocurrir en todo aprendizaje, alcanza un 'auto-conocimiento' y una madurez moral (Bloom 1982):

You must learn not only to judge but to act for yourself $(E V: 164)^{8}$.

Eso es lo que, con todo afán, persiguen Mary (1788) y Maria (1798) ${ }^{9}$ de Mary Wollstonecraft, en unos tiempos en que la moda es una mujer pasiva, un objeto decorativo: "fashionable girls", "mere machines" (MY 5). Lo realmente extraño entonces era atreverse a desarrollar las inquietudes intelectuales y a buscar el conocimiento y la experiencia como hacen Mary y Maria. La primera renunciará a atarse a un marido impuesto por interés, viajará a Portugal, etc. La segunda animará a su hija, por medio de un diario escrito en sus últimos días, a no dejar pasar la vida sin llegar a conocer las verdaderas posibilidades que ésta ofrece y a olvidar la obediencia a la tradicional e impuesta pasividad ${ }^{10}$ :

From my narrative, my dear girl, you may gather the instruction, the counsel, which is meant rather to exercise than influence your mind. [...] I would [...] lead you very early in life to form your grand principle of action, to save you from the vain regret of having, through irresolution, let the spring-tide of existence pass away, unimproved, unenjoyed.- Gain experience - ah! gain it - while experience is worth having, and acquire sufficient fortitude to pursue your own happiness; it includes your utility, by a direct path. What is wisdom too often, but the owl of the goddess, who sits moping in a desolated heart; around me she

\footnotetext{
5 "It is through assuming the powers the romances offer that Arabella can command a space, assert a woman's right to 'a room of one's own' (...). She is allowed her own way -and her own words- a surprising amount of time. She speaks, emphatically and at length, when according to conduct books and contemporary rules a young unmarried woman should remain totally silent. (Doody 1989: xxv).

${ }^{6}$ F. Burney, Evelina, Oxford, Oxford University Press (World"s Classics), [1778] 1982. De ahora en adelante, EV.

${ }^{7}$ Es un modelo de éxito popularizado por Samuel Richardson en su Pamela (1740). Como señalaba Ellen Moers (Moers 1977: 175), Richardson se sentía muy identificado con las mujeres, puesto que él tampoco había disfrutado de una educación formal y también se había sentido un "intruso" en el terreno literario.

8 "In its thematic movement 'Evelina' focuses upon the adventures of its heroine: and though many of them are laughable, they often bring her perilously close to disaster. Through it all she manages to skirt the pitfalls. Each escape, in short, becomes one more step in her progress towards self-knowledge and in the assurance of a happy resolution." (Bloom 1982: XXXV).

${ }^{9}$ M. Wollstonecraft, Mary and Maria, Harmondsworth, Penguin, [1788; 1798] 1992). De ahora en adelante $M Y$ (Mary) y MA (Maria).

Esta autora es muy conocida por la obra de reivindicación de los derechos de la mujer A Vindication of the Rights of Women (1792).

${ }^{10}$ Maria está convencida de que, muchas veces, la sabiduría queda dormida en el corazón de una mujer y no sale al exterior por falta de valentía.
} 
shrieks, but I would invite all the gay warblers of spring to nestle in your blooming blosom. (MA: 95).

\section{HACIA LA REDEFINICIÓN DEL 'YO' FEMENINO}

Durante el siglo XIX las autoras jugaron a emplear una "doble voz" para adecuarse aparentemente al modelo de "ángel" femenino, prototipo de la época, pero subvertirlo de forma sutil entre líneas. Aunque fueron especialistas en ello las escritoras victorianas de la época dorada, como las Brontë, Elizabeth Gaskell, Elizabeth Barrett Browning, Harriet Martineau o George Eliot, resultaron inestimables precursoras autoras como Jane Austen o Maria Edgeworth.

Women from Jane Austen and Mary Shelley to Emily Brontë and Emily Dickinson produced literary works that are in some sense palimpsestic, works whose surface designs conceal or obscure deeper, less accesible (and less socially acceptable) levels of meaning. (They achieved) true female literary authority by simultaneously conforming to and suverting patriarchal literary standards (Gilbert y Gubar 1979: 73).

Elinor y Marianne (Jane Austen, Sense and Sensibility, 1811) ${ }^{11}$ dejan el campo en busca de nuevas experiencias con el beneplácito de su madre:

It is very right that you should go to town; I would have every young woman of your condition in life acquainted with the manners and amusements of London. ([1811] 1992: 129).

La tímida y obediente Fanny Price (Jane Austen, Mansfield Park, 1814) ${ }^{12}$, como Evelina, no encuentra problema alguno hasta que se atreve a expresar su voluntad propia frente a su tutor Sir Thomas y a rechazar a Mr Crawford como pretendiente: "you have now shewn me that you can be wilful and perverse, that you can and will decide or yourself" (MP: 318), por eso es acusada de "self-willed, obstinate, selfish, and ungrateful." (MP: 319). Fanny obtiene, a lo largo de un camino de reflexión y experiencias, una verdadera personalidad y el deseado 'auto-conocimiento' (cf. Bush 1975: 132), descubre las ventajas de viajar: "the novelty of travelling" (MP: 369) y, como Evelina (1778) o Clara Maugham (Margaret Drabble, Jerusalem the Golden, 1967), se sorprende cuando, por fin, hace algo por sí misma: "amazed at being any thing in propia persona, amazed at her own doings in every way..." (MP: 390-391).

También Matilda (Mary Shelley, 1820) ${ }^{13}$ descubre la importancia de ser útil para sentirse realizada (MAT: 202- 3). Cuando las aciagas circunstancias que rodean su vida la llevan a aislarse del resto del mundo, se refugia en el estudio (MAT: 189- 190). Como ella, Maria (1798), Agnes Grey (Anne Brontë, 1847) ${ }^{14}$, Jane Eyre (Charlotte Brontë, 1847) o Frances Henri (Charlotte Brontë, The Professor, 1857) buscan desarrollar sus posibilidades, ante todo, y sentirse útiles a pesar del sufrimiento y las penalidades que la búsqueda, sin duda, conllevará:

\footnotetext{
${ }^{11}$ J. Austen, Sense and Sensibility, Hertfordshire, Wordsworth Editions, [1811] 1992.

${ }^{12}$ J. Austen, Mansfield Park, Harmondsworth, Penguin, [1814] 1966. De ahora en adelante, MP.

${ }^{13}$ M. Shelley, Matilda. Harmondsworth, Penguin, [1959] 1992. En realidad, la fecha de 1820 corresponde al año del envío a imprenta. Esta obra no ha sido publicada hasta 1959 dado el escabroso tema del amor incestuoso de un padre por su hija. (De ahora en adelante, MAT).

${ }^{14}$ A. Brontë, Agnes Grey, Hertfordshire, Wordsworth Editions, [1847] 1994.
} 
How delightful it would be to be a governess! to go out into the world; to enter upon a new life; to act for myself; to exercise my unused faculties; to try my unknown powers; to earn my own maintenance [...] (Agnes Grey, [1847] 1994: 7).

De igual modo, Dinah Morris, la mujer dedicada a predicar públicamente (George Eliot, Adam Bede, 1859) ${ }^{15}$, encuentra en la 'dedicación' y el 'conocimiento' la fuente de su realización personal: "The more knowledge a man has, the better he'll do's work..." ( Eliot [1859] 1960: 489).

\subsection{La "nueva mujer"}

Esta búsqueda encuentra su auge cuando a partir de fines del XIX las novelas empiezan a preocuparse por la 'auto-conciencia' o 'conciencia del yo' (self-consciousness; self-awareness). A medida que va creando, la novelista comienza a apercibirse de la fragmentación del mundo y de su propio ser y, en su búsqueda de respuestas, obliga al lector a una doble visión: por un lado, aprehender la narración y, por otro, el propio proceso creativo de dicha narración (Schwarz 1989: 7-27).

Durante las dos últimas décadas del siglo XIX se escriben y se leen con avidez obras de ideología "feminista". A su vez, las autoras, conscientes de su papel, se sienten cómplices con sus "hermanas" en sufrimiento ${ }^{16}$, como expresaba Olive Schreiner.

Esta autora, con The Story of an African Farm (1883) ${ }^{17}$, se convierte en fundamental impulsora del cambio desde la novela victoriana a la modernidad (Bristow 1992). La protagonista de su obra, Lyndall, para Showalter (1982: 199) la primera heroína verdaderamente feminista de la novela inglesa, es el prototipo de heroína en busca del saber. Desde niña lo tiene claro:

(2) There is nothing helps in this world but to be very wise, and to know everything -to be clever. ... I must learn. [...] I want things of my own. When I am grown up there will be nothing I do not know (AF: 12).

En busca de sus sueños de conocimiento va a un colegio y termina descubriendo sólo una cosa, que la educación que se da a las mujeres no es la verdadera:

(3) I have discovered that of all cursed places under the sun, where the hungriest soul can hardly pick up a few grains of knowledge, a girl's boarding-school is the worst. They are called finishing schools, and the name tells accurately what they are. (AF: 151).

La búsqueda de la verdad y del conocimiento conllevará, irremisiblemente, un sufrimiento y la protagonista lo sabe: si opta por no seguir anclada en la cómoda cotidianidad, sufrirá como

\footnotetext{
${ }^{15}$ G. Eliot, Adam Bede, London, Dent \& Sons, [1859] 1960.

${ }^{16}$ Así se expresa Olive Schreiner (1982) en From Man to Man. London: Virago.

${ }^{17}$ O. Schreiner, The Story of an African Farm. Oxford, O.U.P. (World's Classics), [1883] 1992. De ahora en adelante, $A F$.
} 
Jesús en el desierto, como Moisés en busca de la Tierra Prometida ${ }^{18}$; $\sin _{\text {embargo, }}$ piensa que de todas las experiencias se aprende: "experience will inevitably teach us" $(A F: 136)^{19}$.

Lyndall es pionera y precedente de la "Nueva Mujer" del siglo XX. Para nosotros es, sin duda, un precedente sin parangón al exponer casi dos decenios antes del siglo XX uno de los problemas fundamentales planteados en la modernidad, el descubrimiento de la propia identidad:

(4) In the dark night, when WE are afraid, WE pray and shut OUR eyes. WE press OUR fingers very hard upon the lids, and see dark spots moving round and round, and WE know they are heads and wings of angels sent to take care of US, seen dimly [...] as they move round OUR bed. It is very consoling.

In the day WE learn OUR letters, and are troubled because WE cannot see why k-n-o-w should be know. [...] They tell us it is so because it is so. WE are not satisfied [...]

Beyond the 'kopje' grow some pale-green, hairy-leaved bush. WE are so small, they meet over OUR head; and WE sit among them, and kiss them, and they love US back: it seems as though they were alive.

One day WE sit there and look up at the blue sky, and down at OUR fat little knees; and suddenly it strikes US, Who are WE? This I, what is it? WE try to look in upon ourself, and ourself beats back upon ourself. Then WE get up in great fear and run home as hard as WE can. WE can't tell anyone what frightened US. WE never quite lose that feeling of self again. (AF: 102-3).

El reiterado pronombre de primera persona ("we") en un momento dado se hace reflexivo; la niña, que podríamos ser y de hecho somos todas, acaba de comprender que forma parte de la

\footnotetext{
${ }^{18}$ Las alusiones bíblicas son muy frecuentes en The Story of an African Farm. En realidad, la obra es una crítica, entre otras muchas, hacia las "instituciones sociales", como el cristianismo. (cf. Bristow 1992).

${ }^{19}$ En tono profético y metafórico, Lyndall anuncia:

He who sets out to search for Truth must leave these valleys of superstition for ever... alone he must wander down into the Land of Absolute Negation and Denial; he must abide there; he must resist temptation; when the light breaks he must arise and follow it into the country of dry sunshine. The mountains of stern reality will rise before him: he must climb them: beyond them lies Truth. (AF: 126).

Como Maria (1798) aconsejaba a su hija, Lyndall aconseja a su amigo Waldo que luche por un objetivo en su vida:

If you go into the world aimless, without a definite object, dreaming - dreaming, you will be definitely defeated, bamboozled, knocked this way and that. In the end you will stand with your beautiful life spent, and nothing to show (...).

It does not matter what you choose, -be a farmer, business-man, artist, what you will, -but know your aim, and live for that one thing... Taste everything a little, look at everything a little; but live for one thing. Anything is possible for a man who knows his end and moves straight for it, and for it alone...

Supposing a woman, young, friendless as I am, the weakest thing on God's earth. But she must make her way through life. What she would be she cannot be because she is a woman; so she looks carefully at herself and the world about her, to see where her path must be made (...). This is her end; but how to reach it? Before her are endless difficulties: seas must be crossed, poverty must be endured, loneliness, want... Your life must go for something ( $A F$ : 182- 185).
} 
creación como los árboles o el cielo, del mundo que la rodea, y que es un ser independiente de los demás ${ }^{20}$.

Sin embargo, el descubrimiento del "yo" puede ir, paradójicamente, acompañado de una sensación de "desdoblamiento", en la busca de esa fuerza y confianza en uno mismo. Es muy frecuente encontrar protagonistas contemplándose y conversando con su imagen en el espejo, como hace Lyndall repetidamente. Ella se desdobla en "ella" y "la del espejo", el "yo" se convierte en un "nosotras" ("tú", la del espejo, y "yo"):

(5) THE LARGE DARK EYES from the glass looked back at HER. SHE looked deep into THEM.

'We are all alone, you and I,' SHE whispered; 'no one helps us, no one understands us; but we will help ourselves.' THE EYES looked back at HER... 'We shall never be quite alone, you an I,' SHE said, 'we shall always be together, as we were when we were little' (AF: 210).

(6) SHE looked into the glass on the opposite wall [...] Such A TRANSPARENT LITTLE FACE, refined by suffering into an almost angel-like beauty. THE FACE looked at HER; SHE looked back, laughing softly [...] (AF: 250).

(7) Slowly raising HERSELF on HER elbow, SHE took from the sail a glass that hung pinned there [...] THE WHITE FACE ON THE PILLOW looked into THE WHITE FACE IN THE GLASS. THEY had looked at EACH OTHER often so before [...], 'We are not afraid, you and I; we are together; we will fight, you and II.'Now tonight it had come to this. THE DYING EYES ON THE PILLOW looked into THE DYING EYES IN THE GLASS [...] (AF:252).

\section{LA AUTOAFIRMACIÓN}

La búsqueda de la propia identidad que caracteriza especialmente al siglo XX tiene fiel reflejo en una autora como Dorothy Richardson. Su Pilgrimage, una serie de novelas que absorbió prácticamente toda su vida artística, no es sino la peregrinación, como su nombre indica, o la búsqueda por parte de Miriam Henderson de su 'auto-conciencia', de su 'autoidentidad'. En la primera obra que constituye la serie, Pointed Roofs $(1915)^{21}$, conocemos a Miriam, una chica con verdadera obsesión por ser aceptada y agradar a los demás (PR: 24; 51; 54; 151 y ss.), como parece ser norma general en tantas heroínas, que, como Lyndall (1883), Mrs Ramsay (1927), Julia Martin (1930) o Kate Brown (1973), se "desdobla" entre el "tú" que observa en el espejo (el que sigue los gustos de los demás) y su propio "yo" (PR: 24; 151 y ss.). Un trabajo como profesora en Alemania le aportará parte de la seguridad en sí misma que necesita para forjar su propia personalidad: "She felt strong and independent. She would play, to herself. ...she had almost forgotten her wretched self" (PR: 56).

Mrs. Ramsay (Virginia Woolf, To the Lighthouse, 1927)22, como Lyndall (1883) o Miriam (1915), también siente la necesidad de observar su imagen en el espejo; Mrs. Ramsay necesita

\footnotetext{
${ }^{20}$ El descubrimiento del "yo", en ocasiones, puede ser traumático cuando éste se siente aislado del resto de los seres: "Why am I alone, so hard, so cold? I am so weary of myself! It is eating my soul to its core. -self, self, self! II cannot bear this life! I cannot breathe, I cannot live! Will nothing free me from myself?' (AF: 209).

${ }^{21}$ D. Richardson, Pilgrimage (I): Pointed Roofs, London, Virago, ([1915] 1979). De ahora en adelante, PR.

${ }^{22}$ V. Woolf, To the Lighthouse, Harmondsworth, Penguin, [1927] 1964. De ahora en adelante, TL.
} 
valorar, como Kate Brown (1973), en lo que el tiempo la ha convertido ${ }^{23}$. Su entrega a los demás toda su vida la ha hecho olvidar su realización personal y no le queda nada suyo por lo que conocerse a sí misma ${ }^{24}$ :

(8) So boasting of her capacity to surround and protect, there was scarcely a shell of herself left for her to know herself by; all was so lavished and spent [...] (TL: 45)

No obstante, Mrs. Ramsay empieza, tímidamente, a "descubrir su propio yo" a los cincuenta, cuando los demás van dejando de necesitarla y ella, como le ocurrirá a Kate Brown, empieza a tener tiempo para pensar:

(9) She took a look at life, for she had a clear sense of it there, something real, something private, which she shared neither with her children nor with her husband. (TL: 69)

(10) [...] when they went to bed... she could be HERSELF, by HERSELF. And that was what now she often felt the need of - to think; well not even to think. To be silent; to be alone. All the being and the doing [...] evaporated; and one shrunk, with a sense of solemnity, to being ONESELF, [...] something invisible to others. Although she continued to knit, and sat upright, it was thus that she felt herself [...].

She looked up over the knitting ... and it seemed to her like her OWN eyes meeting her OWN eyes, searching as she alone could search into her mind and her heart [...] (TL: 72- 74).

Como en el pasaje donde la narradora de African Farm (1883) describe el descubrimiento del 'propio yo', en este pasaje también se reiteran los reflexivos, reflejo del proceso de concienciación acerca del propio yo (self-awareness).

Sin embargo, para Mrs. Ramsay es demasiado tarde para completar esa búsqueda y acaba sus días sin llegar a conocerse totalmente:

(11) [...] she wanted something more, though she did not know, could not think what it was that she wanted [...]. There is something I want - something I have come to get, and she fell deeper and deeper without knowing quite what it was [...] (TL: 135- 136).

Esta inseguridad contrasta con los sentimientos de independencia y necesidad de 'autorealización' de otro personaje femenino de la misma obra, su amiga la artista Lily Briscoe, una joven segura de sí misma:

(12) [...] she liked to be alone; she liked to be herself; she was not made for that [...] (TL: 58). y contrasta también con la protagonista de After Leaving Mr Mackenzie (Jean Rhys, 1930) ${ }^{25}$, Julia Martin, muy similar a Lily en este aspecto:

\footnotetext{
23 "When she looked in the glass and saw her hair grey, her cheek sunk, at fifty, she thought, possibly she might have managed things better [...]" (TL: 9).

${ }^{24}$ Su receptividad hacia los demás la ha llevado a la "autodestrucción" (Cf. Showalter 1982: 296).

But what have I done with my life? thought Mrs Ramsay, taking her place at the head of the table, and looking at all the plates making white circles on it [...] she (had) only this - an infinitely long table and plates and knives [...]. She had a sense of being past everything, through everything, out of everything [...] (TL: 95-96).

${ }^{25}$ J. Rhys, After Leaving Mr Mackenzie, Harmondsworth, Penguin, [1930] 1971. De ahora en adelante, ALM.
} 
(13) She felt complete in herself, detached, independent of the rest of humanity. (ALM: $13)$.

Sin embargo, este otro extremo de la balanza tampoco satisface a estas protagonistas más independientes y, tanto Lily como Julia, terminarán dándose cuenta de que, como los demás, también necesitan cariño ${ }^{26}$. Al igual que Lyndall (African Farm) y Mrs. Ramsay, se sienten solas y, en ocasiones, "divididas". Julia Martin describe cómo "ella" se desdobla en "ella" y "su verdadero yo", el "yo" es un "yo" frente a un "tú"27.

(14) I felt as if the woman in the picture were laughing at me and saying: "I am more real than you. But at the same time I am you." And I felt as if all my life and all myself were floating away from me like smoke and there was nothing to lay hold of - nothing. (ALM: 41).

(15) She felt as though her real self had taken cover, as though she had retired somewhere far off and was crouching warily, like an animal, watching her body in the armchair [...] (ALM: 9).

Si Lyndall (1883) describía la experiencia del descubrimiento del propio yo, Julia Martin (ALM: 1930) describe la renuncia de una mujer a su identidad en favor de los demás y sus posteriores intentos de recuperarla (como hará Kate Brown en The Summer before the Dark, Doris Lessing, 1973):

(16) Every day is a new day. Every day you are a new person...

When you are a child you are YOURSELF and you know and see everything prophetically. And then suddenly something happens and you stop being YOURSELF; you become what others force you to be. You lose your wisdom and your soul (ALM: 114- 115).

Julia, como otras protagonistas, tampoco se reconoce en el papel que se espera de ella, por eso abandona el hogar en 'busca de experiencia y conocimientos'. Al igual que Mary Hooligan (Edna O'Brien, Night, 1972) o Kate Brown (Doris Lessing, 1973), vuelve al hogar, pero Julia lo hace insatisfecha porque no ha sabido encontrar lo que buscaba ${ }^{28}$. Sus intentos de cambiar de vida también son infructuosos (ALM: 129-131), no hay vuelta atrás, y como Maria (1798) se pregunta qué utilidad ha tenido su vida ${ }^{29}$ :

(17) All the time she listened she was thinking: 'After all, what have I done? I haven't done anything.' [...] 'Pars, sans te retourner, pars.' An unlucky song. (ALM: 133).

\footnotetext{
${ }^{26} \mathrm{Si}$ en To the Lighthouse Mrs. Ramsay no termina de encontrar lo que busca debido a su vida sacrificada a los demás, su antítesis, Lily Briscoe, tampoco lo encuentra viviendo para sí misma: "She remained a skimpy old maid, holding a paint-brush on the lawn." (TL: 205). Los extremos no suelen satisfacer a una mujer; ambas se alejaron del equilibrio.

${ }^{27}$ Como Lyndall o Mrs. Ramsay, Julia necesita contemplarse en el espejo para recobrar la autoconfianza, retoca continuamente su maquillaje para sentirse fuerte ( $A L M: 11 ; 31 ; 35 ; 45 ; 48 ; 51 ; 65 ; 66 ; 86$ y ss.): "She looked at herself in the glass and thought: 'After all, I'm not finished. It's all nonsense that I am. I'm not finished at all” (ALM: 45).

${ }^{28} \mathrm{Ni}$ el tío de Julia Martin ni el padre de Mary Hooligan las reciben con los brazos abiertos: "[...] it was idiotic of me to come. It's childish to imagine that anybody care what happens to anybody else." (ALM: 61).

${ }^{29}$ La decisión tomada le ha dado una vida de independencia, pero cree que ya es tarde para que alguien le quiera dar amor.
} 
Pese a todo y, como consecuencia de muchas experiencias decepcionantes, la mujer va empezando a descubrir de forma paulatina que para ser feliz debe ser "ella misma" y no autoimponerse reglas o actitudes que conformen ningún papel.

En este descubrimiento puede ser vital la ayuda de otra mujer que así lo haya experimentado. Camilla (Elizabeth Taylor, A Wreath of Roses, 1949) ${ }^{30}$ tiene mucho que agradecer a su amiga Liz en este sentido:

(18) Then I met Liz [...]. For the first time in my life I gossiped, I giggled, I confided, I talked about clothes, I threw away [...] my personal code which was only a rigid and preconceived set of rules [...] (Taylor [1949] 1964: 90- 91).

El "saber" sigue siendo fundamental para llegar a un profundo 'auto-conocimiento'. Así, Miss Jean

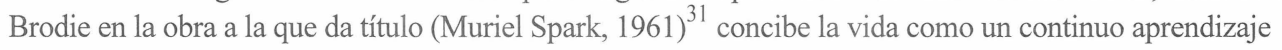

(19) [...] she differed from the rest of the teaching staff in that she was still in a state of fluctuating development [...]. There was nothing Miss Brodie could not yet learn, she boasted of it [...] it was not a static Miss Brodie (Spark 1961:43) ${ }^{32}$.

La oferta de posibilidades para las mujeres iba incrementándose gradualmente a medida que avanzaba el siglo XX, pero no decrecía de igual modo el sentimiento de insatisfacción. La mayor gama de experiencias en el mundo público suponía a su vez 'nuevas responsabilidades' a las que las mujeres debían adaptarse; además, la antes no experimentada posibilidad de 'elección' provocaba miedos y frustraciones: su pequeño mundo privado frente al gran mundo público exterior.

Por otro lado, el 'autodescubrimiento' gradual hacía a la mujer tomar conciencia de su condición como tal e iba creciendo una más sólida 'conciencia de grupo' (ya desde principios de siglo Virginia Woolf había apreciado un creciente interés de las escritoras por el resto de las mujeres) $)^{33}$.

Entre fines de los sesenta y principios de los setenta, Margaret Drabble, Edna O'Brien y Doris Lessing se plantean en sus novelas aspectos fundamentales para las novelistas de siempre, pero más acuciados por las características de ese siglo y, en especial, de estas décadas. Debaten acerca del papel de la mujer en la sociedad, sus relaciones con la familia y el mundo exterior, sus relaciones sexuales y emocionales y los problemas de adaptación de mujeres con grandes inquietudes intelectuales.

En Jerusalem the Golden (1967), Night (1972) y The Summer before the Dark (1973), Margaret Drabble, Edna O'Brien y Doris Lessing, respectivamente, nos presentan a tres

\footnotetext{
${ }^{30}$ E. Taylor A Wreath of Roses, London, Virago, [1949] 1964.

${ }^{31}$ M. Spark, The Prime of Miss Jean Brodie, Harmondsworth, Penguin, 1961.

${ }^{32}$ Miss Brodie no es la única de su generación con tal actitud. Como señala la narradora: " There were legions of her kind during the nineteen-thirties, women from the age of thirty and upwards, who crowded their war-bereaved spinsterhood with voyages of discovery into new ideas and energetic practices in art or social welfare, education or religion" (Spark 1961: 42).

${ }^{33}$ Según Woolf, empiezan a escribir sobre ellas mismas como no se había hecho antes, pues, hasta entonces, las imágenes de las mujeres en la literatura eran creaciones masculinas (V. Woolf en Barrett (ed.) 1979). Además, las mujeres comienzan a sentirse libres para hablar abiertamente de sus experiencias físicas y emocionales como mujeres (cf. Jennifer Breen (1990) In Her Own Write. London, Macmillan).
} 
protagonistas, Clara Maugham, Mary Hooligan y Kate Brown, tres mujeres que de forma análoga a los héroes míticos recorren un largo proceso, un viaje en busca de su propia identidad $^{34}$. No son tres mujeres aisladas, sino, en terminología de Jung, verdaderos arquetipos míticos.

En Jerusalem the Golden ${ }^{35}$, siguiendo un estilo bastante tradicional, Margaret Drabble presenta la vida de Clara Maugham ${ }^{36}$. A lo largo de una estructura lineal, rota por un largo salto atrás a su infancia y adolescencia, conocemos a una joven marcada por su "gran inteligencia no apreciada" ("her intelligence [...] made her an object of ridicule and contempt" $(J G: 8)$ ), cuyas únicas faltas parecen ser "her existence and her sex" (JG: 7). Tiene que crearse su propio mundo de fantasía como vía de escape (sus himnos, lecturas...), ya que no tiene a quien demostrar su afecto ("she has affetion in her, and nowhere to spend it" $(J G: 55))^{37}$, llegando a emplear su belleza física como arma para atraer amigas y novios ( $J G$ : 49 y ss.)

En un determinado momento reflexiona y descubre que, para poder apreciar de verdad la vida, debe conocer y en busca de ese 'conocimiento' deja su barrio de Northam ("such barren territory. Northam was to her the very image of unfertile ground [...]. She hated her home town." $(J G: 27))^{38}$ y viaja a Londres: "she herself was so perpetually aware that without knowledge she had no means of liking or disliking [...]" (JG: 11). Clara debe 'aprender' para superar su falta de confianza en sí misma, su inseguridad, para encontrar una verdadera personalidad ${ }^{39}$ :

(20) She was in truth so unsure of her own taste. (JG: 19).

(21) Clara often found herself wondering what her mother would think. (JG: 123).

(22) It was hard work the acquiring of opinions, and she felt unresentful envy for those like Gabriel and Clelia, those who had been born with views, those who had known from infancy which pictures to pin up on their walls. Clara's walls were bare, from indecision. (JG: 157).

Esta clara falta de identidad domina su vida, hecho en parte provocado por su nula identificación con su propio nombre de pila $(J G: 7)^{40}$ :

(23) She had been attracted by surfaces, by clothes and manners and voices and trivial strange graces, and she had imitated what she had seen of these things in others. She was drawn unquestionably to the appearance of things [...] she had followed many a false

\footnotetext{
${ }^{34}$ El punto de vista narrativo siempre es el de estas mujeres. Sólo Night está narrado en primera persona, pero en los otros dos casos el narrador omnisciente se identifica constantemente con su protagonista.

35 M. Drabble, Jerusalem the Golden, Harmondsworth, Penguin, [1967] 1969. De ahora en adelante, JG.

${ }^{36}$ Nos evoca repetidamente a novelistas victorianas como las Brontë o George Eliot. (Cf. Cunningham 1982: 130- 152 y Showalter 1982: 304).

${ }^{37}$ La relación con su propia madre es traumática; para Clara su madre es "a bloody-minded sadistic hypocrite" (JG: 58).

${ }^{38}$ Clara es una buena semilla que ha caído en terreno baldío, estéril, como en la parábola del sembrador.

${ }^{39}$ Su habitación refleja su vacío interior: "[it] meant nothing, [...] spoke of nothing, [...] betrayed her in no way" (JG: 81).

${ }^{40}$ Además, sus relaciones familiares están marcadas por la frialdad, reflejada en la no utilización de nombres de pila: "She was not accostumed to names. He parents, friendless, respectable, disconnected, used surnames only [...]" $(J G$ : 122)
} 
trail [...]. She knew that her affection for Peter de Salis sprang at the first most ignobly from his delightful name ( $J G: 88)$.

El descubrimiento fundamental o 'anágnorosis' en su búsqueda es el conocimiento de la familia Denham, quienes le muestran el verdadero afecto:

(24) The Denhams led her, quite literally, into areas that she had never visited before (JG: 111).

(25) $[\ldots]$ she had not been taught to love, she had lacked those expensive, private lessons ( $J G$ : $165)$.

Lejos de esas amigas y novios juveniles, de su superficialidad, descubre la verdadera amistad en Clelia y el verdadero amor en Gabriel. De ser una chica sin identidad pasa a ganar seguridad, con los hombres y con la esfera pública, y a valorar profundamente las cosas, a las personas y a sí misma ${ }^{41}$.

También Night $^{42}$ de Edna O'Brien es el reflejo de esa 'búsqueda de la identidad' por parte de una mujer.

A través de una noche de vigilia Mary Hooligan hace un rápido recorrido por su vida con una pregunta última "¿quién soy?". En forma de monólogo interior se nos presenta un viaje mental en busca de la propia identidad. De nuevo, partimos de una mujer que se siente sola y confusa:

(26) I am in a bed [...]. I lie with my God, I lie without my God. Oh Connemara, oh sweet mauve hills, where will II go, where will II not go? (NT: 7- 8).

para quien la memoria es su única compañía en esa noche de búsqueda:

(27) I have had unions, tête-à-têtes [...] (NT: 9).

(28) There was a time when I made jam and met my son Tutsie, as he came through the school gates [...] $(N T: 11)^{43}$.

Como Clara Maugham, es una mujer con problemas de identidad que necesita "autoafirmarse" continuamente:

(29) I am a woman [...] (NT: 9).

(30) I'm called Mary. Mary Hooligan [...] (NT: 51).

(31) As usual I was unrecognizable to myself, I nearly always am unless I'm doing something ordinary like planting a bulb [...] or making a batter for pancakes $(N T: 55)^{44}$.

\footnotetext{
${ }^{41}$ El descubrimiento del diario de su madre contribuye a erradicar su sentimiento de desarraigo, contribuye al "encuentro con su propio yo" y al verdadero aprecio de la vida: "She felt, for the first time, the satisfaction of her true descen $\ell^{\prime}$. (JG: 197); "(Clara) had merely wanted to live". (JG: 160 y 201); "Even the mercy and kindness of destiny she would survive" [...] (JG:206).

42 E. O'Brien, Night, Harmondsworth, Penguin, 1972. De ahora en adelante; NT.

${ }^{43}$ Su sucesión de recuerdos va desde su infancia, a sus amantes, a sus comidas favoritas, a muestras de religiosidad, sus trabajos... Mary se siente como una verdadera víctima y sus recuerdos suelen ser negativos, con continuas referencias a la "oscuridad" (NT: 73- 74, 78).

${ }^{44}$ Cuando se siente vacía de identidad intenta identificarse de forma nostálgica con lo que hacía antes, el papel doméstico, como Julia Martín.
} 
Y, como Lyndall (African Farm) o Julia Martin (After Leaving Mr Mackenzie), Mary Hooligan intenta encontrar su identidad frente a su imagen en el espejo ${ }^{45}$.

También, como hiciera Clara Maugham (Jerusalem the Golden), comienza un viaje por los recuerdos. Recuerda cómo en su búsqueda de 'realización personal' dejó a su familiar y su hogar, su pueblo Coose en Irlanda y se fue a Liverpool (NT: 22). Como Clara, se siente inestable e insegura y viaja esperando encontrar fuera algo que la llene. Una vez más, Mary Hooligan también es una mujer llena de afecto que no encuentra a quien dárselo ${ }^{46} \mathrm{y}$, quizá por esta razón, recurre a diversas aventuras amorosas y trabajos ${ }^{47}$. Una visita al hogar le demuestra que volver atrás no es ya posible, tiene la misma sensación que Julia Martin al volver a casa:

(32) There is no magic, no homecoming, no handshake, no loving cup... And still the journey is not without its come hithers, not without challenge, not without incentive (...) (NT: 119).

Aunque la vida no parece haberse portado muy bien con ella y pese a sus pesimistas palabras de un principio ("I want to be myself at last and to be robbed of that stupid, suppurating malady they call hope" (NT: 11)), pese a su sensación de soledad ("I am getting used to my own company, my own dissertations." (NT: 49)), la larga reflexión nocturna la lleva a un bello descubrimiento: la vida es dura pero hay que seguir luchando. El despertar del día deja en su boca una oración de esperanza:

(33) I am up now, limbering [...] Oh lamb of God [...] Oh Connemara, oh sweet mauve forgotten hills [...].

Oh star of the morning, oh slippery path, oh guardian angel of mortals, givvus eyes, lend us a hand, let's kip down on some other shore, let's live a little before the all-embracing dark descends (NT: 121-122).

Finalmente, en The Summer before the Dark $(1973)^{48}$ Doris Lessing presenta a Kate Brown, una mujer más que, en un determinado momento de su vida, se detiene para cuestionarse acerca de su propia existencia: "My life has changed because I have changed" (SBD: 7). Kate es una mujer madura que, como Mrs. Ramsay (To the Lighthouse) o Susan (The Waves $)^{49}$, ha sacado una casa adelante, a un marido y unos hijos. La perspectiva de un verano sola la hace reflexionar acerca de su pequeña vida privada y temer el choque con el mundo público exterior:

(34) She felt like a long-term prisoner who knows she is going to have to face freedom in the morning (SBD: 18).

(35) she felt [...] as if suddenly a very cold wind had started to blow, straight towards her, from the future (SBD: 19).

\footnotetext{
45 "I try, I try so hard to recollect [...] - to remember the then [...] what I saw of myself, mis-saw, when I looked into one of the many long, sad, blotched mirrors [...]" (NT: 13).

${ }^{46}$ Cuando ve a unas niñas: "I could have eaten their smiles [...]", "times like that I am forgetful and laughing" (NT: 96).

${ }^{47}$ Como Julia Martín, Mary encuentra amantes pero no amor. Edna O'Brien, irlandesa y católica, sienta escuela porque es la primera mujer de ese entorno en mostrar gran libertad sexual en sus novelas. (Cf. Darcy O'Brien 1982: 179- 190).

${ }^{48}$ D. Lessing, The Summer before the Dark, Harmondsworth, Penguin, 1973. De ahora en adelante, SBD.

${ }^{49}$ V. Woolf (1931) The Waves, London, The Hogarth Press.
} 
Se da cuenta de que siempre ha sido lo que se esperaba de ella: "[...] a wonderful mother, a cook for the angels, a marvellous, marvellous being, all warmth and kindness, with not a fault in her [...]" (SBD: 17), de que las características de su vida han sido la pasividad y el adaptarse a los demás (SBD: 21): "Patience. Self-discipline. Self-control. Self-abnegation. Chastity. Adaptability to others -this above all. This always." $(S B D: 89)^{50}$. Descubre que siempre ha visto la vida desde la barrera:

(36) Kate Brown, [...], her self, her mind, her awareness, watching the world from behind a façade. (SBD: 44)

Kate, como Julia Martin (After Leaving ...) o Lyndall (African Farm), también es una mujer ante su imagen en el espejo (SBD: $150 ; 153 ; 158-9 ; 168-9$ y ss. $)^{51}$. Pero el espejo le devuelve la imagen que ha cultivado para los demás, no a la verdadera Kate.

Ahora un trabajo de traductora e intérprete le va a permitir "desarrollar sus posibilidades" ${ }^{15}$. Como Clara y Mary, siente que con un 'mayor conocimiento' de las cosas se aprende a vivir más profundamente: "What matters most is that we learn through living [...] We are what we learn" $(S B D: 8)^{53}$. Necesita saber y sentirse útil: "I've never done anything [...] I've just brought up a family [...]" (SBD: 178)

Ante la necesidad de cambiar ("What was she going to do about this monster inside which she was trapped?" (SBD: 166)), en su búsqueda entran en juego ingredientes que hemos visto en las anteriores novelas: viajes (Turquía, también España como Clara y Mary) y una aventura amorosa. Pero, al final del verano, decide regresar a casa.

Pese a que algunos críticos como S.J. Kaplan (1982) consideren este regreso al hogar como un fracaso de la protagonista, para nosotros no vuelve la misma persona. La Kate que se marchó estaba destinada a satisfacer un papel ante los demás, en tanto que la que regresa es una nueva Kate que ha cumplido un proceso de "maduración interior" y que ha descubierto cómo ser ella misma.

De hecho, desde un principio y durante toda la novela, cuando la protagonista realizaba algo que se esperaba de ella según su papel social, la narradora la denominaba "una mujer" (" $a$ woman": SBD: 5- 11; 30; 36; 43- 47; 135; 146; 150; 153; 158; 169; 176; 190 y ss.). Sin embargo, a medida que empieza a actuar según su verdadera personalidad, esa "mujer" va a recobrar de forma significativa su nombre y se va a ir transformando en "Kate".

\footnotetext{
50 "She had 'worked' on that smile [...] Awful! Why do I do it?" (SBD: 15); "Like her own life. Farcical." (SBD: 147).

${ }^{51}$ She was not surprised to see that a monkey looked back at her from the mirror (SBD: 150).

Had she really spent so many years of her life - it would almost certainly add up to years! - in front of a glass? Just like all women. ... For the whole of her life ... she had looked into mirrors and seen what other people would judge her by. And now the image had rolled itself up..., leaving the face of a sick monkey (SBD: 153). Kate stopped in front of a long old-fashioned swing-mirror in the hall. She saw a thin monkey of a woman inside a 'good' yellow dress (...) (SBD: 158).

52 "[...] there must be something I could be seeing now, something I could be understanding now, some course of action I could choose [...] Choose? When do I choose? Have I ever chosen?" (SBD: 10).

${ }^{53}$ Palabras similares a las de Lyndal en la obra de Schreiner, a las de Clara Maugham en la novela de Margaret Drabble (JG: 160, 201) y a las de tantas otras protagonistas.

${ }^{54}$ Aunque éste no haya sido fácil, para Kate su papel de madre y esposa no ha sido suficiente para realizarse. (Cf. Kaplan 1982). Sus palabras son similares a las de Susan en "Susan's Monologue", V. Woolf, The Waves.
} 
"Kate's long interior journey" (SBD: 193) $)^{55}$ finaliza con un acto simbólico, no teñirse el pelo, que podríamos considerar como equivalente a no querer mostrarse tal y como se esperaría de ella, superficialmente, sino tal como ella verdaderamente se siente y es:

(37) Her experiences of the last months - her discoveries, her self-definiton, what she hoped were new strengths - were concentrated here: she would walk into her home with her hair undressed, with her hair tied straight back for utility; [...] the widening grey band showing like a statement of intent. It was as if the rest of her, body, feet, even face, which was ageing but amenable, belonged to someone else. But her hair - no! ( $S B D$ : 230).

\section{CONCLUSIÓN}

Aunque la verdadera lucha por encontrar la propia identidad es característica del siglo $\mathrm{XX}^{56}$, sin duda, las raíces se hallan en los sentimientos encontrados y divididos del 'yo' romántico y, si volvemos la vista aún más atrás, descubriremos que, quizá de forma algo más inconscientemente, desde las primeras obras, la mujer siempre ha reflejado esa necesidad del saber, de la experiencia, de la auto-realización, en definitiva, de ser alguien con 'identidad propia'.

Los esquemas de mujeres, a menudo solas e incomprendidas (por su inteligencia, por sus inquietudes...), que deciden emprender la búsqueda de conocimiento y experiencias, que dejan el hogar, deciden viajar, conocer amistades o aventuras amorosas, trabajar y desarrollar las posibilidades propias... son tema común y persistente en las obras.

La búsqueda supone sacrificio, sufrimiento y cansancio acumulados, pero éstos merecen la pena pues, tras el esfuerzo, llegarán a saber más, a conocerse más a sí mismas, y a descubrir que la felicidad no está solamente fuera sino que también depende de la actitud interior.

Esas búsquedas míticas en cada novela, desgraciadas unas, con éxito otras, no son sino pasos, a su vez, de esa gran búsqueda que, en nuestra opinión, ha supuesto la novela escrita por mujeres. Bien es cierto que, por un lado, ha habido numerosas trabas en la trayectoria, mucho desconocimiento y falta de contacto entre las mujeres; pero, pese a ello, al tiempo que nuestras escritoras describían búsquedas de ficción, escribían, a la vez, su episodio en la gran 'novela de concienciación y búsqueda' que es, para nosotros, la historia de la novela escrita por mujeres. Estas mismas autoras eran las protagonistas de ese viaje en pos de la 'identidad propia femenina' y de la realización de las posibilidades y aptitudes aún no valoradas en la mujer. 'La historia de la novela femenina' se podría comparar a un gran Bildungsroman, una gran novela de 'desarrollo' a través del cual las mujeres han madurado, han sufrido, pero han llegado, finalmente, al convencimiento de que, como Kate Brown o tantas otras, han de ser 'ellas mismas', no la imagen de lo que se espera de ellas. También han descubierto que no hay que escapar de forma radical ni física ni mentalmente de otros papeles tradicionales como el del hogar, sino que lo importante es la actitud nueva y sin encadenamientos.

La búsqueda no ha acabado, aún quedan muchas posibilidades y aptitudes que desarrollar, y muchas cosas por decir. Todo lo que durante siglos se ha tenido que callar.

\footnotetext{
${ }^{55}$ Su búsqueda de la identidad progresaba paralela a un "sueño" recurrente, cuando concluye el sueño, también Kate ha culminado esa búsqueda de la auto-definición.

${ }^{56}$ Cf. el libro de A. Giddens (1992) Modernity and Self-Identity.
} 


\section{REFERENCIAS BIBLIOGRÁFICAS}

\section{FUENTES PRIMARIAS}

AUSTEN, Jane, Sense and Sensibility, Hertfordshire, Wordsworth Editions, [1811] 1992.

AUSTEN, Jane, Mansfield Park, Harmondsworth, Penguin, [1814] 1966.

BRONTË, Anne, Agnes Grey, Hertfordshire, Wordsworth Editions, [1847] 1994.

BRONTË, Charlotte, Jane Eyre, London, Longman, [1847] 1991.

BRONTË, Charlotte, The Professor, Hertfordshire, Wordsworth Editions, [1857] 1994.

BURNEY, Fanny, Evelina, Oxford, Oxford University Press (World's Classics), [1778] 1982.

CAVENDISH, Margaret, The Blazing World and Other Writings, Harmondsworth, Penguin, [1656; 1666] 1992.

DRABBLE, Margaret, Jerusalem the Golden, Harmondsworth, Penguin, [1967] 1969.

ELIOT, George, Adam Bede, London, Dent \& Sons, [1859] 1960.

LENNOX, Charlotte, The Female Quixote, Oxford, Oxford University Press. (World's Classics), [1752] 1989.

LESSING, Doris, The Summer before the Dark, Harmondsworth, Penguin, 1973.

O'BRIEN, Edna, Night, Harmondsworth, Penguin, 1972.

RHYS, Jean, After Leaving Mr Mackenzie, Harmondsworth, Penguin, [1930] 1971.

RICHARDSON, Dorothy, Pilgrimage (I): Pointed Roofs, London, Virago, ([1915] 1979).

SCHREINER, Olive, The Story of an African Farm. Oxford, O.U.P. (World's Classics), [1883] 1992.

SCHREINER, Olive, From Man to Man, London, Virago, ([1927] 1982.

SHELLEY, Mary, Matilda. Harmondsworth, Penguin, [1959] 1992.

SPARK, Muriel, The Prime of Miss Jean Brodie, Harmondsworth, Penguin, 1961.

TAYLOR, Elizabeth, A Wreath of Roses, London, Virago, [1949] 1964.

WOLLSTONECRAFT, Mary, A Vindication of the Rights of Women, Harmondsworth, Penguin, [1792] 1975.

WOLLSTONECRAFT, Mary, Mary and Maria, Harmondsworth, Penguin, [1788; 1798] 1992)

WOOLF, Virginia, To the Lighthouse, Harmondsworth, Penguin, [1927] 1964.

WOOLF, Virginia, The Waves, London, The Hogarth Press, 1931.

\section{FUENTES SECUNDARIAS}

BARRETT, M.(ed.),) Virginia Woolf: Las mujeres y la literatura, Barcelona, Lumen, ([1979] 1981.

BLOOM, E., Fanny Burney: Evelina, (introducción y notas al texto), Harmondsworth, Penguin, 1982.

BREEN, J., In Her Own Write. London, Macmillan, 1990. 
BRISTOW, J., Olive Schreiner: The Story of an African Farm. (introducción y notas al texto), Oxford, Oxford University Press, 1992.

CUNNINGHAM, G., "Women and children first: the novels of Margaret Drabble" en Thomas Staley (ed.) Twentieth-Century Women Novelists. London, Macmillan, 1982, pp. 130- 152.

DOODY, M. A., Charlotte Lennox: The Female Quixote, Oxford, Oxford University Press, 1989.

GILBERT, S.M. y GUBAR, S., The Madwoman in the Attic. The woman Writer and the Nineteenth-Century Literary Imagination, New Haven, Yale University Press, 1979.

GIDDENS, A. Modernity and Self-Identity, London, Polity Press, 1992.

KAPLAN, S. J., "Passionate portrayal of things to come: Doris Lessing's recent fiction" en Thomas Staley (ed.) Twentieth-Century Women Novelists. London, Macmillan, 1982.

MOERS, E., Literary Women: The Great Writers, London, The Women's Press, 1977.

O'BRIEN, D., "Edna O'brien: a kind of Irish childhoold" en Thomas Staley (ed.)), TwentiethCentury Women Novelists. London, Macmillan, 1982, pp. 179-190.

SANDERS, A., The Short Oxford History of English Literature, Oxford, O.U.P., 1994.

SCHWARZ, D. R., Transformation of the English Novel, 1890-1930, London, Macmillan, 1989.

SHOWALTER, E., A Literature of Their Own: from Charlotte Brontë to Doris Lessing, London, Virago, 1982. 
